MARCELO ACACIO RODRIGUES

UMA CONTRIBUIÇÃO PARA O ESTUDO DAS DEFORMAÇÕES RESIDUAIS PROPORCIONADAS PELO PROCESSO DE USINAGEM POR FRESAMENTO.

Tese apresentada a Escola Politécnica da Universidade de São Paulo para obtenção do Título de Doutor em Engenharia Mecânica

São Paulo

2009 
MARCELO ACACIO RODRIGUES

\title{
UMA CONTRIBUIÇÃO PARA O ESTUDO DAS DEFORMAÇÕES RESIDUAIS PROPORCIONADAS PELO PROCESSO DE USINAGEM POR FRESAMENTO.
}

\author{
Tese apresentada a Escola Politécnica \\ da Universidade de São Paulo para obtenção \\ do Título de Doutor em Engenharia Mecânica \\ Área de concentração: \\ Engenharia Mecatrônica e de \\ Sistemas Mecânicos
}

Orientador: Prof. Dr. Amauri Hassui

São Paulo

2009 
Aos meus pais Valdir e Maria das Graças e a minha irmã Patricia.

Verdadeiros refúgios durante a tempestade.

Ensinaram-me ternura, espírito de luta e fé.

Não me faltou nada no caminho, apenas palavras de gratidão.

De Selvagem, marmita e tatuagem, a Vitória é nossa. 


\section{Agradecimentos}

À Iara Ferraz pela inestimável ajuda e por permanecer forte e sonhadora apesar das dificuldades do caminho. Fez parte do processo e ajudou na travessia mais pesada. Minha gratidão por ti é ilimitada. VSSM.

Ao Prof. Doutor Amauri Hassui pela sabedoria e destreza para tratar com seu mais intransigente (porém disciplinado) aluno. Fez silêncio no momento certo e disse aquilo que devia ser dito na hora que precisei.

Aos engenheiros e engenheiras da Equipe Poli-Baja. Recebi desta equipe muito mais do que doei, por isso estarei sempre em dívida com todos. O pódio é uma conseqüência. A vitória é reservada a quem trabalha e isto vocês já sabem como fazer.

Aos companheiros do Muay Thai. A disciplina da vida é a disciplina da luta. Guarda baixa, golpe entra. Guarda alta, proteção eterna. Luta com mais fraco, ensine. Luta com mais forte, aprenda. A posição de discípulo é um mérito.

Ao Eng ${ }^{\circ}$ Lucas Tadeu Silva Moreira. Sábias palavras durante a tempestade surgem de quem a gente menos espera. São poucos aqueles que trocam seis por três, e isto no final vale mais que mil, pode acreditar.

À Guhring Brasil Ferramentas e Editora Aranda - Máquinas e Metais. Por acreditar em mim e me proporcionar um perfeito laço com a indústria, condição indispensável para a pesquisa e para a vida.

Ao Laboratório de Fenômenos de Superfície da EPUSP por me oferecer abrigo, dúvidas e trabalho. Um obrigado especial ao Eng ${ }^{\circ}$ Mario Vitor por seu apoio na alquimia dos nobres metais.

Aos meus alunos de Salamanca, do Cursinho Humanista, da Uniban, da Poli-USP e de todas as salas de aula que ainda hei de entrar nesta vida. O ingrediente da verdadeira revolução é pó de giz, e isto é obra nossa, alunos e professores, eternamente.

À Deus, Criador de tudo e todos. Por colocar-me no jogo que suporto e livrar-me de todo medo. Por guiar meus passos na derrota e na vitória e ensinar-me a dividir para multiplicar. Esconde-se no gesto e não na forma e ensina que feliz é aquele que vive para o próximo.

\section{Obrigado.}

